\title{
Performance Appraisal Fundamentals, Practices and Challenges in Public Sector: Case of Adigrat Town, Ethiopia
}

\section{Premkumar Balaraman}

$\mathrm{PhD}$, Associate Professor, Department of Management Studies, Adigrat University, Ethiopia

Tsega Gebre

MBA, PG Researcher, Department of Management Studies, Adigrat University, Ethiopia

\section{Gebremeskel Berhe}

M.A. (Development Studies), Assistant Professor, Department of Management Studies, Adigrat University, Ethiopia

\section{Priya K}

MBA, Assistant Professor, Department of Management Studies, SRM University, India

\begin{abstract}
PURPOSE \& AIM: In Ethiopian Context, the modern Performance Appraisal practices and its implementation are still in its nascent stage, and there exists a gap in understanding the mechanism of performance appraisal processes in the case of Ethiopia's public sector organizations, which employs a significant proportion of the working population. The study was conducted to assess performance appraisal practices and challenges in the public sector, specifically the Case of Adigrat town, Ethiopia and also reexamine the fundamentals of Performance Appraisal from Literature review.

METHODOLOGY: The study used both primary and secondary data sources. Cross-sectional survey was used and 174 respondents were taken as a sample from a total population of 1213 comprising 19 public sector organization and from each organization, proportionate sampling technique was applied. The questionnaire mainly used 5-point Likert scale items and it was distributed to the employees of public sector organization on the basis of simple random sampling. The collected data through questionnaire were analyzed using statistical techniques such as frequencies, mean, standard deviation and ANOVA.
\end{abstract}

FINDINGS \& CONCLUSION: Majority of employees are evaluated with same criteria, and it becomes difficult to know individual's performance regarding their knowledge, skill and other aspects as they differ in weightage because of varied job duties and responsibilities. There exists carelessness in hearing and addressing employees' problem regarding performance appraisal and evaluation standard is not revised by the responsible authority. Performance appraisal is biased because of partiality by supervisors, also team coordinators lack proper training in assessing and giving feedback.

The major performance appraisal challenges raised from interviewees are, not having computer skill, no consistent training for appraiser and appraisee, subjective criteria's (attitude), self-evaluating by two weeks' culture in giving performance results etc. Based on the findings it is inferred that the performance appraisal process is at a moderate level, employees are well aware of the criterions for performance appraisal, implementation of performance appraisal methods is not at the desired level. Therefore, it is recommended that the public sector should improve its performance appraisal practices to ensure the availability of efficient and effective employees in all organizations, especially in the Case of Ethiopia (Adigrat).

Keywords: performance appraisal, methods, criteria, challenges, public sector.

JEL Classification: M51, L32.

Cite as: Balaraman, P., Gebre, T., Berhe, G., Priya, K. (2018). Performance Appraisal Fundamentals, Practices and Challenges in Public Sector: Case of Adigrat Town, Ethiopia. Business Ethics and Leadership, 2(4), 1834. http://doi.org/10.21272/bel.2(4).18-34.2018.

(C) The Authors, 2018. This article is published with open access at Sumy State University.

\section{Introduction}

Employee's performance appraisal is one of the most important activities of every organization because the success or failure of any organization depends on various resources. From those, human resource is the most 
vital one. The importance of performance evaluation as a managerial decision tool depends on whether or not the performance appraisal system is able to provide accurate data on employee performance and therefore rating precision is a critical characteristic of the appraisal process. A complexity of getting exact appraisals of employee's job performance is often credited to: errors in rating format used, deficiencies in appraisal content, rater resistance to judge others, and the inference of the specific purpose of appraisal for the rater and the ratee (Adeba, 2014). A research regarding human resource management practices towards organizational performance in the case of Addis Ababa University indicated that there was lack of sound performance appraisal system, unsystematic training process and lack of fair and objective promotion practices (Asrat, 2016). In addition to this, in the case of Ministry of Culture and Tourism Ethiopia, the findings are; the main setback of performance appraisal in the ministry of culture and tourism are bias, lack of employees' involvement, non-alignment between performance standards and employee's job, lack of capability to evaluate by the evaluators (Adeba, et al.).

\section{Need for the Study}

The real facts about performance appraisal in public sector are: employee engagement goes down significantly when they do not conduct performance appraisal on regular basis, organizations that conduct frequent appraisal experience lower turnover costs, employees do not undertake responsibility when they get little or no feedback and employee's satisfaction directly reflects on external customers. Organizational performance is the synergetic sum total of the performance of employees in the organization. This being the fact, employee's performance has to be closely planned, coached and appraised to ensure it is in line with the interest of the organization. However, it seems that performance appraisal is not given the accurate attention by most organizations and is exercised like a normal process rather than as a tool of motivation on the basis of which several of administrative and developmental decisions are taken. By considering the above facts, the study on Performance Appraisal Practices and Challenges in Public Sector is undertaken as there is no prior study undertaken on the issue performance appraisal practices and challenges in public sector in Adigrat town.

\section{Significance of the Study}

This study covered the practices and challenges of performance appraisal of the public sector organizations in Adigrat town. The findings of this study have provided for the public sector to identify gaps and to make the necessary adjustment in the practice of performance appraisal mechanism. It helps employees of the public sector to know how they are evaluated and to identify purposes of the performance appraisal. It also helps the researcher to acquire knowledge and skills and it serves as a reference for future researchers who intend to pursue their study in the related area. Henceforth the need and significance of the study are best justifiable, as the deeper understanding of practices and challenges of performance appraisal system of the public sector shall lead to Good Employee Governance, Ethical Leadership and Infusion of Scientific and Contemporary Human resource practices in running the Organization.

\section{Objective of the Study}

\section{General Objective}

$>$ To assess the Performance Appraisal Practices and Challenges in Public Sector (Case of Adigrat town, Ethiopia).

\section{Specific Objectives}

$>$ To Reexamine and Clarify the fundamentals of Performance Appraisal from Literature.

$>$ To assess the Performance Appraisal Process in Public Sector of Adigrat town.

$>$ To assess Performance Appraisal Methods practiced in Public Sector of Adigrat town.

$>$ To explore the Performance Appraisal Criterions in Public Sector of Adigrat town.

$>$ To assess the Performance Appraisal Challenges in Public Sector of Adigrat town.

\section{Literature Review}

\subsection{Definition and Concept of Performance Appraisal}

Performance evaluation is a regular evaluation of the individual with reverence to his or her performance on the work and his or her perspective for development. More expansively, it is an official, prearranged system of measuring and evaluating an employee's job-related behaviors and outcomes to find out how and why the employee is presently performing on the job and how the employee can perform more effectively in the future so that the employee, organizations, and society all benefit (Aswathappa, 2002). 
Performance evaluation is a scheme intended to periodically and regularly measure the performance of employees against pre-set principles and it involves providing comment to the employees in which case the result of the appraisal will be used as a basis for administrative decisions and developmental purposes (Ivancevich, 2004). Performance assessment procedure come across its roots in the scheming function of management whereby the manager promises whether employees are performing up to the pet level of the organization or not. Performance appraisal is indispensable for organizations in abundant ways like it serves as a relatively more intention basis for judging the merit of employees for encouragement, transfer or termination of employees and helps in distinguishing between efficient and inefficient workers (Saqib, et al., 2012).

Armstrong (2010) describes the role of the performance appraisal as a tool for looking forward to what needs to be done by people in the organization in order to achieve the purpose of the job to meet new challenges. Once tasks are assigned to employees in the organization, the management of the organization is supposed to make sure that the tasks are performed as planned accordingly. This could be achieved through performance appraisal. Hence, performance appraisal is a formal system of periodic review and evaluation of an individuals' job performance (Decenzo \& Robbins, 2005). Performance appraisal is considered as a managerial tool for facilitating administrative decision related to the human resource. In other words, the outcomes of performance appraisal should be directed toward the benefit of the organization and individual employee. Generally, performance appraisal serves in almost all-human resource management processes such as: performance improvement, placement decisions, training and development needs, compensation adjustments, equal employment opportunity and so on (Decenzo \& Robbins, et al.).

\subsection{Performance Appraisal Process}

Since the basic purpose of performance appraisal is to make sure that employees are performing their jobs effectively, the process should be carried systematically. As far as the process is concerned, some argue that the top management of the organization should establish performance standards first, then communicate the standards to the employees, then measure actual performance of the employees, then compare it with the established standards and finally, take corrective actions if any(Matthis\& Jackson, 2008).Though there is no rigid procedure to be followed, many writers agree that the process of performance appraisal commonly involves the following basic steps: (1) conducting job analysis; (2) establishing standards of performance; (3) communicating of performance standards to employee, (4) measuring actual performance; (5) comparison actual performance with standards; and (6) Initiating corrective action, if necessary (Aquinas, 2006; Daoanis, 2012; Mamoria \& Rao, 2012).

Job analysis is performed as a basis for improvements, including: definition of a job domain; description of a job; development of performance appraisals, employee job performance standards are established based on the job description. Employees are predictable to successfully execute the duties stated in the job description. Therefore, job descriptions form the wide criteria beside which employees' performance are deliberated. According to Aquinas (2006), a standard is a value or specific criterion against which actual performance can be compared. The standards set for performance must be clearly defined and unambiguous. It should be attainable by the employee and it must be clear to both the appraiser and appraise. For the appraisal system to attain its purposes, the employees must understand the criteria and standards against which their performance is measured. As long as the chance for employees to undoubtedly be aware of the performance standards will improve their incentive and promise towards their jobs. The aim of every appraisal system must be to allow for continuous communication between management and employees about job performance and should be geared for the total improvement of the organization as a whole (Daoanis, 2012). This is the responsibility of the immediate boss to observe the work performance of subordinates and evaluate it against the established job performance standards and requirement.

The aim of the performance measure is to detect departure from the expected performance level. Therefore, it is essential to compare the actual performances with the predetermined performance standards. When the comparison process takes place actual performance may be better than expected and sometimes it may be the opposite. If there is any deviation or not, discussion with the employee will enable to know their weakness and strengths. Weakness is discussed so that employee takes the concentration in improving their performance (Seidu, 2012).

When performance appraisal is properly done, it provides feedback to employees about their performance and thus organizations also benefit by ensuring the employees' effort and ability to make a contribution to organizational success. But if it is poorly done it leads to unsatisfactory results for all concerned. And there is a possibility that in the year under review, the performance of subordinates might not be checked by supervisor 
regularly. In this case, the subordinates do not know how they are performing, and it also creates a problem for them to improve performance in case of any shortcomings or weaknesses. Therefore, it is necessary for supervisors to tell subordinates regularly about how they are working so that they can improve in case of any weakness (Ikramullah, Shah, Hassan, \& Zaman, 2012).

The final step in the performance appraisal process is the initiation of corrective action (if necessary). Corrective action can be two types. One is immediate and deals mostly with a warning sign. The other is basic and studies the causes. The instant remedial act is often described as "relegation or putting out fires", whereas basic counteractive action gets to the foundation of divergence and seeks to regulate the dissimilarity enduringly. Coaching and counseling may be done or special assignments may be seen (Mamoria, \&Rao, et al.).

The practice and process of the performance appraisal in any government employees under Federal Civil Service is according to the proclamation No. 262/2002 declared in chapter four, stating that the federal civil servants proclamation performance evaluation purpose is to enable civil servants (a) effectively discharge their duties in accordance with the expected level quality standard time; (b) identify their strengths and weaknesses; (c) improve their "future performances and develop self-initiative. (d) The performance evaluation shall be transparent and shall be carried out with the collective participation of-civil servants working together. (e) The performance evaluation shall be carried out in accordance with directives issued by the Commission.

\subsection{Performance Appraisal Methods}

We can manage performance by focusing on employee attributes, behaviors, or results. In addition, we can measure performance in a relative way, making overall comparisons among individuals' performance. Finally, we can develop a performance measurement system that incorporates some variety of the preceding measures, as evidenced by the quality approach to measuring performance (Lotich, 2014). There are Traditional and Modern Methods of Performance Appraisal, which have their own importance and area of application.

The Traditional Methods include Ranking Straight (ranking most excellent to the poorest), Comparing by Way of Paired Ranking, Assessment of Linear Rating Scale (graphic method), Evaluation by the Group (Group determines the job performance standards) (Dewakar, 2009).

The Modern Performance Appraisal Methods include Multi-Level Multi-Source Feedback System (360 Degree feedback), Evaluation on the Basis of Result or Management by Objective (MBO), Evaluation on Behaviorally Anchored Rating Scales (BARS), Results Approach, Balanced Scorecard. (Dewakar, et al; Noe, 2008; Paul, 2014).

\subsection{Criteria's to Evaluate Employees in Public Sector}

According to Armstrong (2009), the decisive factor for assessing performance is supposed to be fair between: achievements in relative to objectives; the level of understanding and skills obsessed and applied (competences or technical competencies); behavior in the job as it influences performance (competencies); the degree to which behavior upholds the core values of the organization; day-to-day effectiveness. Employee performance decisive factor are separated below: each criterion should be checked in relation to the individual employee's duties and everyday jobs. Each criterions degree of importance will vary according to the requirement of each employee's job.

The various criterions include, Knowledge of work, Quality of work, Quantity of work, Relationships, Attitude, Dependability and sense of responsibility, Relation with other employees and customers, Initiative at work and to help others, Punctuality on his/her job, Presence on his/her job, Involvement in teamwork.

\subsection{Challenges of Performance Appraisal}

According to Adeba (2014), challenges of performance appraisal are raised from employees and managers side. From employee's face, employees find objectionable performance appraisal for the terror of disparagement on their feeble side of their job performance, dread that their salaries, promotions, and their fate with the organization pivot winning the outcomes of this domino effect. Challenges of the performance appraisal from managers' side include Cultural problem (Avoiding Negative Feedback as it is not part of Organizational Culture), Negative assumption (Lack of confidence on the appraiser by appraise), Mismatched work assignment, Fear of loss of position.

John (2011) with his magazine has explained some challenges/problems with performance appraisal. He categorized them as, most serious performance appraisal challenges, process-related, instrument (form) challenges, manager/execution challenges, employee/subject challenges and timing issues. The most serious 
ones include, not assessing real performance (rather ending up in comparison of manager's traits with the employee), Occasional feedback, Non-data-based assessment, Lack of responsibility.

\section{Conceptual Framework \& Methodology}

The Conceptual framework (Fig. 3.1) and the various operational definitions utilized in the study is presented in the forthcoming section. The domain is very broad in nature, the study restricts itself in assessing the practices of Performance appraisal in Public sector (Adigrat) focused on the Process, Methods, Evaluation criteria and Challenges only.

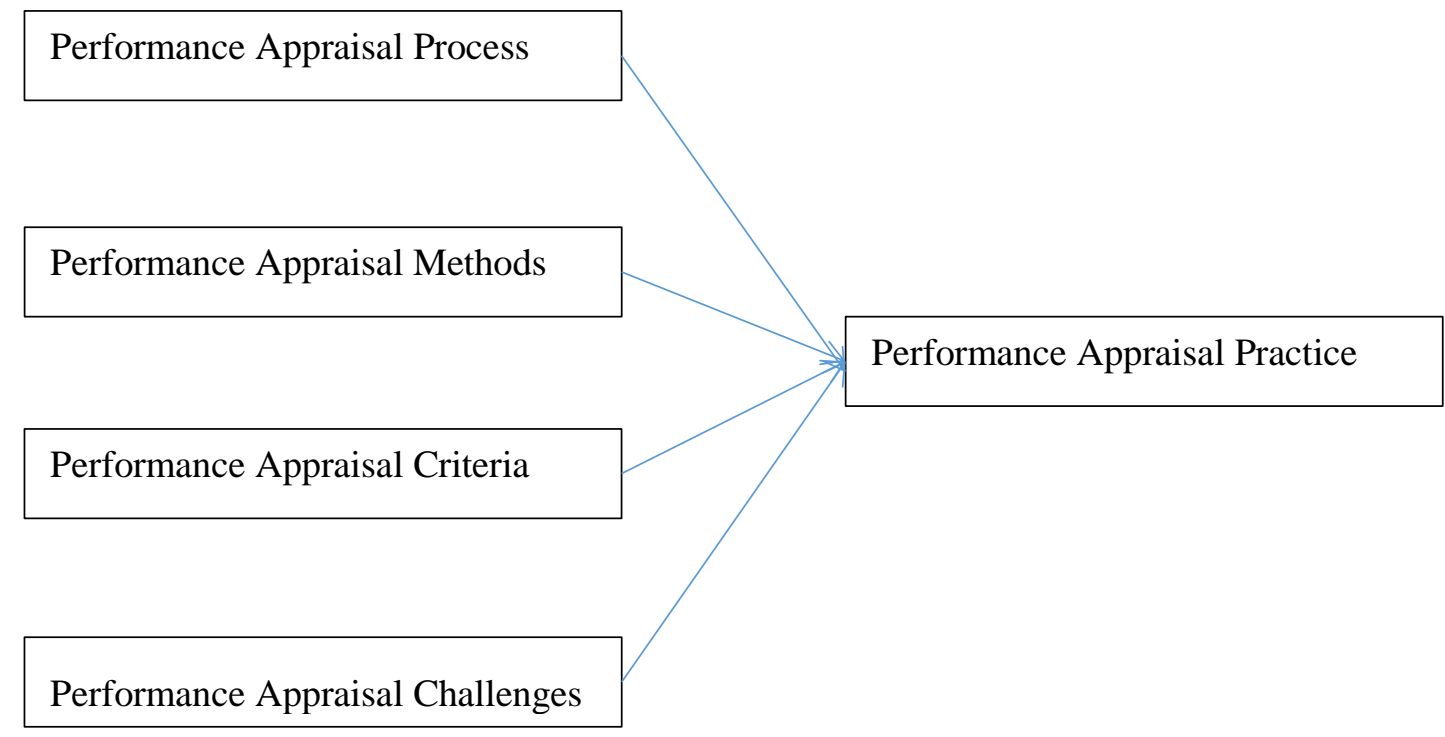

Figure 3.1 Conceptual framework of the study

Source: Noe, 2008; Yong, 1996; Decenzo \& Robbins, 2005; Saqib, et al., 2012

\subsection{Operational Definitions}

Performance appraisal: are the systematic assessments of an employee in terms of the performance aptitude and other qualities, which are necessary for successfully carrying out the job.

Performance appraisal process: finds its ancestry in the scheming purpose of management whereby a manager assures whether employees are performing arts up to the desired level of the organization or not.

Methods of appraisal: a particular practice for accomplishing a job and of employee's evaluation practice.

Challenges: obstacles or impediments that hinder the effectiveness of performance appraisal practices in the public sector.

Thus the paper explores from a qualitative perspective the fundamentals of Performance Appraisal Practice, definitions and its design from Literature; also it studies the Practices and Challenges of Performance appraisal mechanism in Public Sector Organization of Ethiopia (Adigrat) by a Quantitative approach. The detailed Research Design, Data Types, Instruments and Sampling Techniques are discussed in detail in forthcoming sections.

\subsection{Research Design and Strategy}

The research design is a blueprint for selecting the sources and types of data relevant to the research questions. It basically, provides answers for such questions like: what techniques to be used to gather data? And what kind of sampling will be applied? (Zikgmund, Barry, Babine \& Carr, 2003). To collect data, the researcher was used survey research design. This is because the survey design is preferable to conduct research employing a large number of people questioning about their attitudes and opinions towards the specific issue, events or phenomena (Marczyk \& Dematteo, 2005). It also enables the researcher to effectively administer and manage the tasks when the data collection takes place.

This study applied a cross-sectional survey since the data were collected at one point in time from the sample respondents to describe the total population. With regard to research strategies, the study was employed both 
qualitative and quantitative ones. Because the mixed method is considered as a tool to triangulate the result of single approach through multiple methods (Johnston, 2010). A quantitative method is selected because it is viewed as an effective to gather large data and comprehensive issues at a specified period of time (Ngwenya, 2010). While the qualitative method is selected based on the assumption that it enables the researcher to generate meanings and phenomena within the real context of the research participants and to fill the gap left by the quantitative one (Kothari, 2004). Therefore, the mixed method was adopted in order to make the study more reliable through triangulation.

\subsection{Data Types and Sources}

The study was used both primary and secondary data to get consolidated data so as to reach on concrete findings. The primary sources of data were collected from the respondents currently working in their own public sector because employees know the current practices and challenges of performance appraisal. To supplement the primary data, secondary sources were collected through extensive review of human resource management books \& manuals.

\subsection{Study Population}

The target population from which the researcher draw conclusion comprised the employees of 19 public sectors with permanent employees of 1213.

\subsection{Sampling Methods and Sampling Size}

\subsubsection{Sampling Methods}

The sampling method from the total population was probability sampling technique and from each sector, the proportional sampling technique was used. To collect data from the sample respondents, the simple random technique was applied.

\subsubsection{Sample Size}

In the determination of sample size, the three criteria were very important to gather the required data from sample respondents. These included the level of precision, the level of confidence or risk and the degree of variability in the attributes being measured that enable the researcher to determine appropriate sample size (Miauous\& Michener, 1976). Therefore, by considering these issues sample size to collect data through the questionnaire for this study was used Yamane's (1967) formula.

$\mathrm{n}=\frac{N}{1+N(e) 2}=\frac{1213}{1+1213(.07) 2}=174$

Where: $\mathrm{n}=$ the sample size;

$\mathrm{N}=$ the study population (1213);

$\mathrm{e}=$ standard error $(7 \%)$;

$1=$ designates the probability of the event occurring.

Therefore 174 respondents were used as sample size for the study to gather data through the questionnaire. Independent sample was taken from each selected public sector to ensure equal representation because sectors have a different number of employees. Therefore, the sample size for each sector was calculated using proportion. The study was used proportionate sample allocation formula so as to make each sector with the proportion of the population. Therefore, the proportional sample size from each sector was calculated by using the following formula.

$\mathrm{ni}=\frac{n * N i}{N}$

Where: $\mathrm{ni}=$ sample size for each sector;

$\mathrm{Ni}=$ the total number of employees in each sector;

$\mathrm{N}=$ the total number of employees in 19 public sectors (1213) the total sample size of the woreda (174).

Source: (http://ocw.jhsph.edu/courses/statmethodsforsamplesurvey). 
Table 3.1 Sampling Techniques and Sampling Method from Each Public Sector Organization

\begin{tabular}{|c|l|c|c|}
\hline SN & \multicolumn{1}{|c|}{ Data source } & Population & Sample size \\
\hline 1 & Education office & 682 & $174 * 682 / 1213=98$ \\
\hline 2 & Health office & 119 & $174 * 119 / 1213=17$ \\
\hline 3 & Plan and Finance office & 38 & $174 * 38 / 1213=5$ \\
\hline 4 & Construction, road and transport office & 26 & $174 * 26 / 1213=4$ \\
\hline 5 & Trade and industry office & 58 & $174 * 58 / 1213=8$ \\
\hline 6 & Civil service office & 24 & $174 * 24 / 1213=4$ \\
\hline 7 & Security and administration office & 9 & $174 * 9 / 1213=1$ \\
\hline 8 & Government public relation office & 14 & $174 * 14 / 1213=2$ \\
\hline 9 & Youth and sport affair office & 8 & $174 * 8 / 1213=1$ \\
\hline 10 & Labor and Social affairs office & 8 & $174 * 8 / 1213=1$ \\
\hline 11 & Women's affair office & 7 & $174 * 7 / 1213=1$ \\
\hline 12 & Administration office & 21 & $174 * 21 / 1213=3$ \\
\hline 13 & Counseling office & 10 & $174 * 10 / 1213=1$ \\
\hline 14 & Court office & 20 & $174 * 20 / 1213=3$ \\
\hline 15 & Culture and tourism office & 25 & $174 * 25 / 1213=4$ \\
\hline 16 & Micro and small enterprises and UPSN. Development agency & 76 & $174 * 76 / 1213=11$ \\
\hline 17 & Adigrat housing development agency & 14 & $174 * 14 / 1213=2$ \\
\hline 18 & Adigrat town revenue development office & 40 & $174 * 40 / 1213=6$ \\
\hline 19 & Justice office & 14 & $174 * 14 / 1213=2$ \\
\hline Total & & $\mathbf{1 2 1 3}$ & $\mathbf{1 7 4}$ \\
\hline
\end{tabular}

Source: Ethiopia Civil Service Office; 18/4/2010 E.C

\subsection{Data Collection Methods and Instrument}

\subsubsection{Data Collection Instruments}

To increase the breadth of information obtained from the respondents in relation to practices and challenges performance appraisal in public sectors in the case of Adigrat town the study used two types of data collection instruments.

Questionnaires: in this study structured questionnaire were prepared in the form of Likert scale to collect the required data in relation to practices and challenges of performance appraisal in public sectors from the sample employees of Adigrat town. Such data collection instrument was developed in order to gather large data and avoid pressure on the respondents (Creswell, 2003).

Interview: the human language is very useful in opening of what lies behind people's action (Zikgmund, et al., 2004). Interview permits person-to-person conversation that can guide to increase insights into respondents' opinion, approach and performance on practices and challenges of performance appraisal. Another advantage that can be derived from the interview is its flexibility in expressing different viewpoints on the subject under study. Thus, practices and challenges of performance appraisal were interviewed in depth using unstructured questions during the working hours. The respondents were selected through judgmental method because of their closeness to execute the issues.

\subsubsection{Data Collection Procedures}

Gathering the required data in relation to performance appraisal practices and challenges public sectors, a preliminary visit was made in public sector organizations. During that time, secondary data sources pertaining to the subject under study were reviewed and discussions were also held with the particular staff on how and when to make discussions with the respondents. The questionnaires were administered to employees of public sectors during working hours (Monday to Friday) through the researcher's close supervision. While the interview was conducted face to face with a supervisor, case team coordinators and head offices to triangulate the information gathered from questionnaires.

\subsection{Data Analysis Procedures}

Data was analyzed through quantitative and qualitative techniques. The data collected from the questionnaire in the form of the Likert scale was analyzed through quantitative descriptive statistical tools such as percentages, mean and standard deviation using SPSS version 20.0. In this section, the researcher sought the respondents' perception in regards to the performance appraisal process, methods, critical factors and problems 
to show the level of agreement, disagreement and moderate to the statements in the Likert scale of between of 5 to 1: (5: Strongly Agree; 4: Agree; 3: Neutral/Moderate; 2: Disagree; and 1: Strongly Disagree). The scores were calculated to mean scores which were interpreted as 4.5-5.0 strongly disagree; 3.4-4.4 disagree; 2.5-3.4 moderate; 1.5-2.4 agree and 0.0-1.4 strongly agree (Ambani, 2016). While qualitative data obtained through interview was analyzed qualitatively in sentence form. Finally, the results were discussed and interpreted to draw important conclusions, recommendations.

\section{Findings \& Discussion}

\subsection{Demographic Information of the Respondents}

The first part of the questionnaire consists of the demographic information of the participants. This part of the questionnaire requested a limited amount of information related to personal characteristics of respondents. Accordingly, the following variables about the respondents were summarized and described in the subsequent. These variables include age, sex, work experience, educational background and salary.

\subsubsection{Sex of Respondents}

Based on the data presented in Figure 4.1, 61.5\% of the respondents are male and the rest are female. From this Figure, we can easily observe that most of the public sectors employees are males.

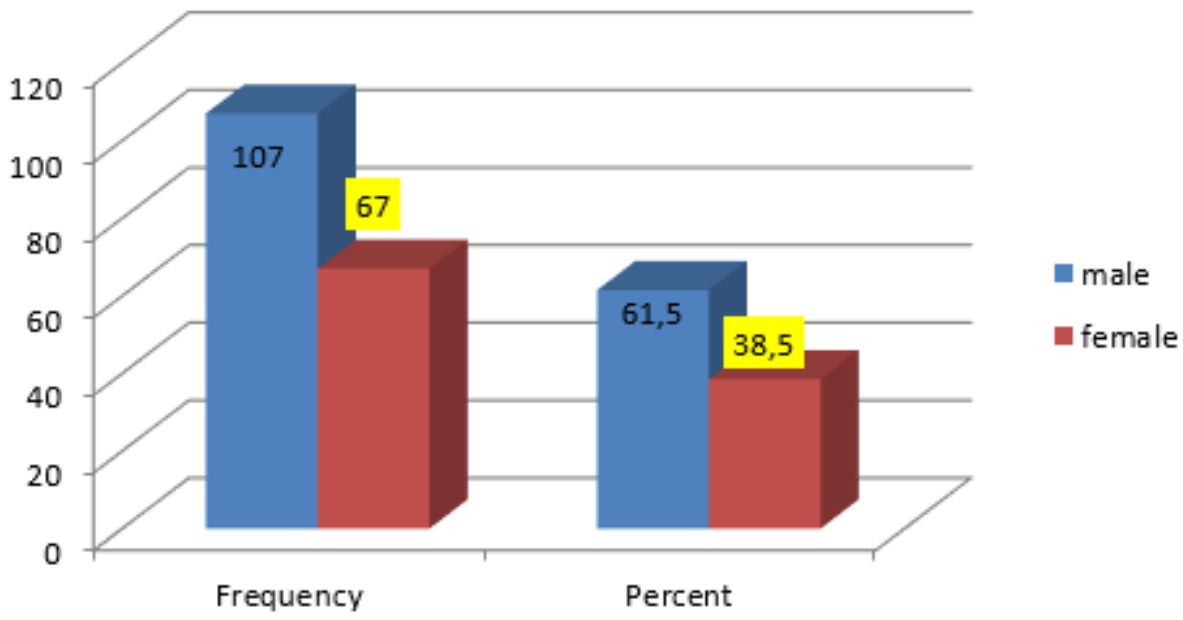

Figure 4.1 Sex of respondents

Source: Own Survey, 2018

\subsubsection{Age Categories of Respondents}

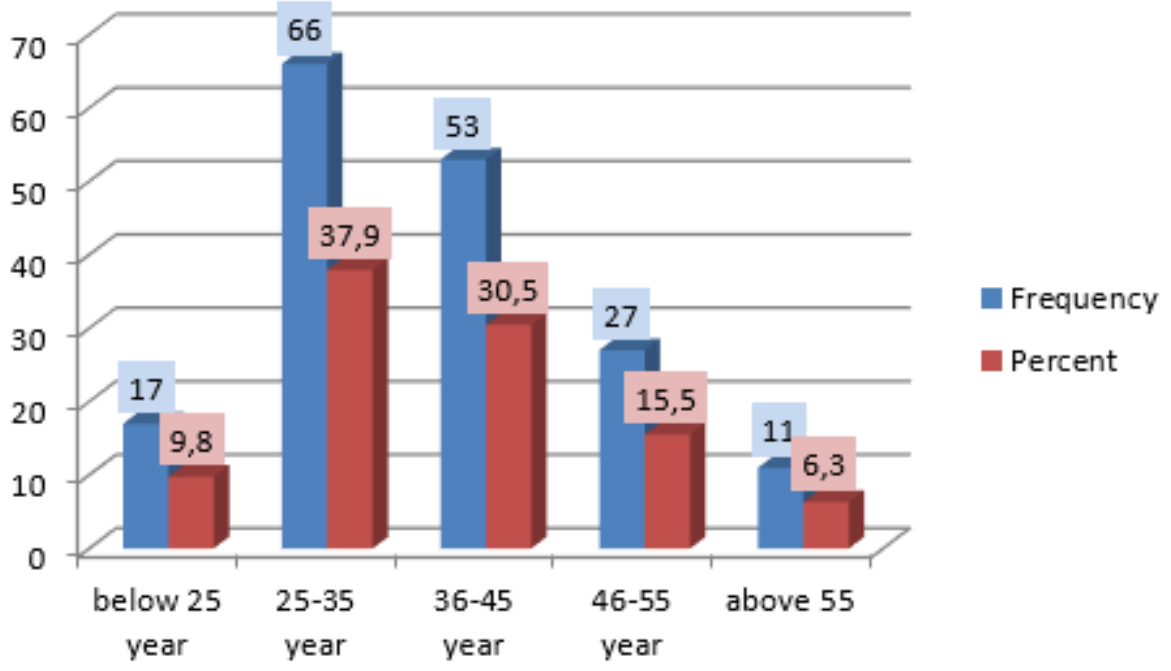

Figure 4.2 Age categories of respondents 
From the above Figure 4.2, the largest number of respondents $37.9 \%$ are in age group of 25-35 years and respondents with age ranging from 36-45 years and from $46-55$ years constitute $30.5 \%$ and $15.5 \%$ respectively. On the other hand, $9.8 \%$ of respondents are below 25 years, while only $6.3 \%$ of respondents are above 55years old. From this result, we can understand that most of the respondents are in the age of 25-35 years or most of the respondents are aged above 26 . To this end, individuals aged above 26 are better at solving problems faced by the organizations systematically. In this regard, the organization's permanent employee's combination is somehow promising.

\subsubsection{Educational Background of Respondents}

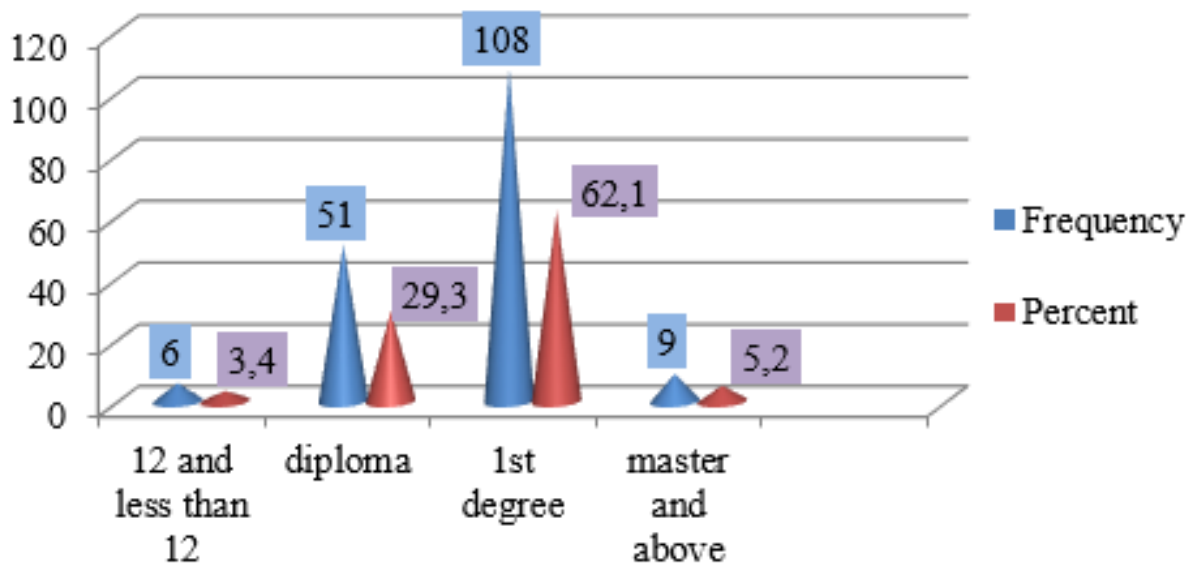

Figure 4.3 Educational background of respondents

Source: Own Survey, 2018

As far as their educational status is concerned, (depicted in the above Figure 4.3), $62.1 \%$ of employees have the first degree and 5.2\% are master and above. $29.3 \%$ are diploma holders, $3.4 \%$ of employees are 12 and below 12 grades complete. It is true that the educational standing of a given individual has a huge deal to do with the efficiency and effectiveness of what he/she performs.

\subsubsection{Salary Category of Respondents}

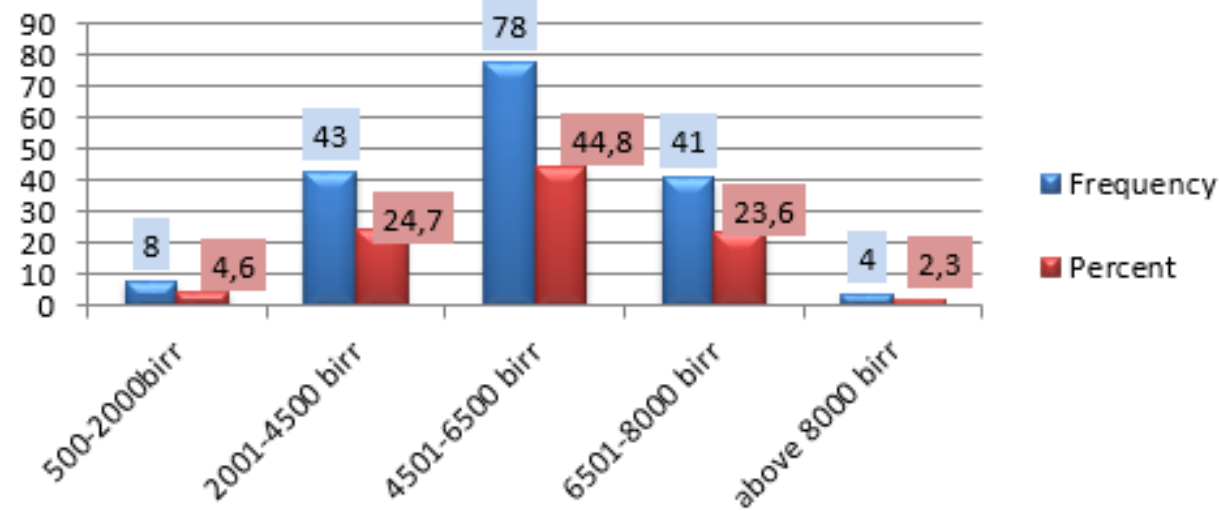

Figure 4.4 Salary categories of respondents

Source: Own Survey, 2018

Regarding salary, $44.8 \%$ of the employees were in the range of $4501-6500$ birr, $24.7 \%$ in the range of 20014500 birr, $23.6 \%$ in $6501-8000$ birr, $4.6 \%$ from $500-2000$ birr and the rest $2.3 \%$ of the employees are greater than 8000 birr. From this, we can understand that the majority of employee's salary is in the range of 45016500. Salary and performance appraisal have the relationship because the end result of performance appraisal is either to increase salary or not.

\subsubsection{Work Experience of Respondents}

Regarding an individual's years of experience, level of experience can add a lot towards the way he/she thinks, the method he/she performs on his/her duty and the like. To this end, it is supposed that the more an individual 
stay on an organization, the more he/she can obtain an experience of how to deal with several problems in his/her workplace, which imprisons leads to minimization of conflict regarding performance appraisal result. With this regard the data collected from the respondents resemble that the largest number of respondents $52.3 \%$ have working experience of above 7 years, $20.7 \%$ are in the range of 5 to 7 years, $14.9 \%$ have 2 to 5 years' experience and the rest $12.1 \%$ of the respondents have less than 2 years of working experience.

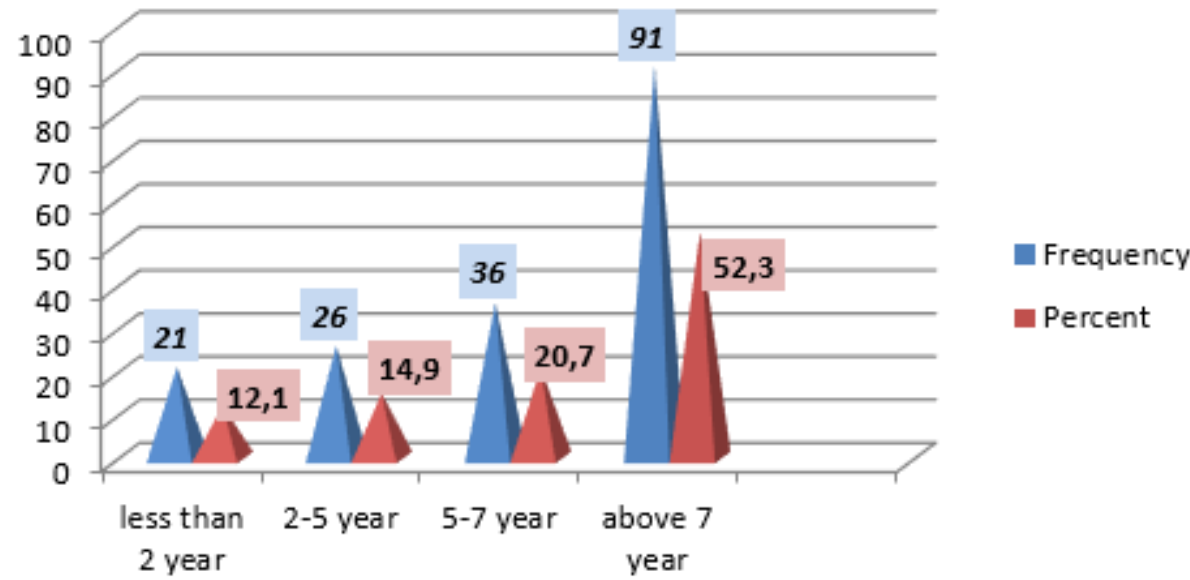

Figure 4.5 Work experience of respondents

Source: Own Survey, 2018

4.2 Employees' Perception on Performance Appraisal Process

Table 4.1 Employees’ Response on Performance Appraisal Process Related Questions

\begin{tabular}{|c|c|c|c|c|c|c|c|c|c|c|c|c|c|c|}
\hline \multirow[t]{2}{*}{ Activities } & \multicolumn{2}{|c|}{$\begin{array}{c}\text { Strongly } \\
\text { agree }\end{array}$} & \multicolumn{2}{|c|}{ Agree } & \multicolumn{2}{|c|}{ Moderate } & \multicolumn{2}{|c|}{ Disagree } & \multicolumn{2}{|c|}{$\begin{array}{l}\text { Strongly } \\
\text { disagree }\end{array}$} & \multicolumn{2}{|c|}{ Total } & \multirow[t]{2}{*}{$\mu$} & \multirow[t]{2}{*}{ SD } \\
\hline & No. & $\%$ & No. & $\%$ & No. & $\%$ & No. & $\%$ & No. & $\%$ & No. & $\%$ & & \\
\hline $\begin{array}{l}\text { The objectives } \\
\text { of PA are clear } \\
\text { to employees }\end{array}$ & 39 & 22.4 & 90 & 51.7 & 33 & 19 & 8 & 4.6 & 4 & 2.3 & 174 & 100 & 2.13 & .891 \\
\hline $\begin{array}{l}\text { PA criteria are } \\
\text { established } \\
\text { based on job } \\
\text { description }\end{array}$ & 38 & 21.8 & 67 & 38.5 & 41 & 23.6 & 23 & 13.2 & 5 & 2.9 & 174 & 100 & 2.37 & 1.055 \\
\hline $\begin{array}{c}\text { Criteria on PA } \\
\text { are associated } \\
\text { with goal }\end{array}$ & 40 & 23 & 73 & 42 & 39 & 22.4 & 16 & 9.2 & 6 & 3.4 & 174 & 100 & 2.28 & 1.029 \\
\hline $\begin{array}{l}\text { Self- } \\
\text { assessment is } \\
\text { allowed prior } \\
\text { to conduction } \\
\text { final result }\end{array}$ & 25 & 14.4 & 87 & 50 & 35 & 20.1 & 24 & 13.8 & 3 & 1.7 & 174 & 100 & 2.39 & .953 \\
\hline $\begin{array}{c}\text { PA is } \\
\text { conducted } \\
\text { fairly without } \\
\text { any bias }\end{array}$ & 7 & 4 & 15 & 8.6 & 28 & 16.1 & 105 & 60.3 & 19 & 10.9 & 174 & 100 & 3.66 & .929 \\
\hline $\begin{array}{l}\text { Employees are } \\
\text { getting further } \\
\text { career } \\
\text { development or } \\
\text { HR decision } \\
\end{array}$ & 23 & 13.2 & 43 & 24.7 & 92 & 52.9 & 16 & 9.2 & 0 & - & 174 & 100 & 2.58 & .83 \\
\hline & & & & & & & & reg & nea & d st: & $\mathrm{rd} \mathrm{c}$ & ation & 2.62 & .92 \\
\hline
\end{tabular}

Source: Own Questionnaire, 2018 
As we can see from the Tables 4.1 to 4.4 , the paper focuses on the significant questions for which the respondents responded strongly and significantly.

From the Table 4.1, for the item on "clarity of objectives of the performance appraisal", $22.4 \%$ strongly agree with the statement that the objective of performance appraisal is clear, $51.7 \%$ agreed followed by the rest of the options. From this, we can understand that majority of the employees have awareness about the objective of performance appraisal and this is supported with mean score 2.13 that respondents positively agreed that the objective of performance appraisal is clear to employees.

Regarding Performance evaluation criteria and standards established, 21.8\% strongly agreed, 38.5\% agreed, $23.6 \%$ moderately agreed followed by other options. The mean score 2.37 also indicate respondents are agreed that performance evaluation criteria and standards of the public sectors are established based on job description. But still, there are criteria that are not established based on job description.

As far as the criteria provided under performance evaluation are associated with the objective and goal of the office, the response is $23 \%$ strongly agreed, $42 \%$ agreed. $22.4 \%$ become moderate. The mean score 2.28 indicates the majority of respondents agreed with the statement that the criteria provided under performance evaluation are associated with objective and goal of the sector. In general, in Adigrat public sectors objective of performance appraisal is clear employees, evaluation criteria and standards are established based on job description. However, this result is not similar to Asrat (2016). In Addis Ababa University there was a lack of clarity with performance appraisal objective and performance evaluation criteria and standard were not established based on job description.

Besides, an interview with some experts of the public sector was conducted and their response was similar that is employees do have a chance to evaluate themselves using proper format. Even though their response is positive i.e. self-assessment is good prior to conduction the final result, they criticize the idea that it takes more time and boring because self-assessment is done two times per month and supervisors do not consider the result of self-assessment. Due to this, employees simply copy and paste once they fill the self-assessment performance details and give to the responsible person to escape from accountability.

As indicated in the above Table 4.1, the majority of the respondents, $60 \%$ disagreed, $10.9 \%$ strongly disagreed that performance appraisal is conducted fairly without any bias. But $4 \%$ strongly agreed, $8.6 \%$ agreed with the statement. While $16.1 \%$ become moderate. Respondents disagreed with the mean of 3.66 to the statement. This indicates that there is biasness in measuring actual performance. This result is similar with (Asrat, 2016).in Addis Ababa University and it denotes that performance appraisal is not conducted fairly and free from biases. To minimize unfairness, self-evaluation helps employees to perceive fairness in the evaluation process. It also creates a chance to discuss evaluators with employees/subordinates and also needs to have in mind that measuring of employee's actual performance needs to be a continuous activity that should be carried out throughout the year hence to identify all the parameters effectively.

The final step in performance appraisal is decision making that can be taken either to improve the performance of the employees, take the required corrective actions, or the related HR decisions like rewards, promotions, demotions, transfers etc. Based on that the response of the employees on employees are getting further career development or promotion as a result of their performance is, $13.2 \%$ strongly agree, $24.7 \%$ agreed while $52.9 \%$ moderate. On the contrary, 9.2\% disagree. Based on that, the responses of employees are getting further career development or promotion as result of their performance is moderate with of mean of 2.58 , which indicates employee's career development or promotion is not at the desired level.

According to the information obtained from Civil Service Office and HR coordinators of different sectors during the interview it is found that employees are getting reward, recognition, long-term training, promotion, short-term training, and job designation is not at the desired level based on their performance. But there is career development after two years for employees of the health center, teachers, industrial extension teachers and employees of information communication technology (ICT). That is the way they give attention to performance appraisal better than the others. 
4.3 Employees Perception on Performance Appraisal Methods Practiced

Table 4.2 Employees Response on How Performance Appraisal Methods Practiced

\begin{tabular}{|c|c|c|c|c|c|c|c|c|c|c|c|c|c|c|}
\hline \multirow[t]{2}{*}{$\begin{array}{l}\text { Activities } \\
\text { /variables }\end{array}$} & \multicolumn{2}{|c|}{$\begin{array}{c}\text { Strongly } \\
\text { agree }\end{array}$} & \multicolumn{2}{|c|}{ Agree } & \multicolumn{2}{|c|}{ Moderate } & \multicolumn{2}{|c|}{ Disagree } & \multicolumn{2}{|c|}{$\begin{array}{l}\text { Strongly } \\
\text { disagree }\end{array}$} & \multicolumn{2}{|c|}{ Total } & \multirow[t]{2}{*}{$\mu$} & \multirow[t]{2}{*}{ SD } \\
\hline & No. & $\%$ & No. & $\%$ & No. & $\%$ & No. & $\%$ & No. & $\%$ & No. & $\%$ & & \\
\hline $\begin{array}{l}\text { Evaluated by } \\
\text { comparing with co- } \\
\text { workers }\end{array}$ & 29 & 16.7 & 120 & 69 & 12 & 6.9 & 10 & 5.7 & 3 & 1.7 & 174 & 100 & 2.1 & 0.79 \\
\hline $\begin{array}{l}\text { Employees are } \\
\text { evaluated } \\
\text { consequentially } \\
\text { prior the final } \\
\text { evaluation } \\
\end{array}$ & 40 & 23 & 85 & 48.9 & 28 & 16.1 & 18 & 10.3 & 3 & 1.7 & 174 & 100 & 2.19 & 0.96 \\
\hline $\begin{array}{l}\text { All criterions are } \\
\text { equally weighted }\end{array}$ & 8 & 4.6 & 24 & 13.8 & 30 & 17.2 & 95 & 54.6 & 17 & 9.8 & 174 & 100 & 3.51 & 1 \\
\hline $\begin{array}{c}\text { There is enough } \\
\text { time to hear and } \\
\text { address employees' } \\
\text { challenges }\end{array}$ & 3 & 1.7 & 18 & 10.3 & 36 & 20.7 & 94 & 54 & 23 & 13.2 & 174 & 100 & 3.67 & 0.9 \\
\hline $\begin{array}{l}\text { The BSC results are } \\
\text { revised by the } \\
\text { responsible } \\
\text { department }\end{array}$ & 7 & 4 & 29 & 16.7 & 40 & 23 & 73 & 42 & 25 & 14.2 & 174 & 100 & 3.46 & 1.1 \\
\hline & & & & & & & & greg & mea & nd st & $\operatorname{ard} c$ & ation & 2.84 & 0.98 \\
\hline
\end{tabular}

Source: Own Questionnaire, 2018

From the above Table 4.2, for the item on "employee's evaluation based on the last few months' performance prior to conducting the final performance appraisal", $23 \%$ strongly agree, $48.9 \%$ agreed, $16.1 \%$ become moderate. The mean score 2.19 indicates almost half of respondents agreed with the statement that employees are evaluated prior to conduction the final result.

According to the above Table 4.2, 4.6\% strongly agreed that the criterions are equally weighted moreover $13.8 \%$ agreed. Out of the respondents, $17.2 \%$ are moderate. But $54.6 \%$ disagreed, $9.8 \%$ strongly disagreed. The mean score 3.5 replies that respondents disagreed that the criteria are equally weighted. This implies that performance evaluation criteria have given different weightages. Since the contribution of each criterion towards the performance of an employee is different, giving different value is a positive side of public sectors system.

Regarding, the item "while conducting the evaluation result, there is enough time to hear and address employees' problem", the response is $54 \%$ disagreed, $13.2 \%$ strongly disagreed whereas $20.7 \%$ moderate. From this, we can understand that the majority of the employees disagree that managers or supervisors are giving time to hear and address employee's problem. This means managers or supervisors are not giving time to hear and address the employee's problem. Since this is one of the techniques that help managers/public sector heads/ to address sensitive and confidential information about employees that hinder their performance, managers, supervisors and case team leaders are required to give time and full attention to interview and hear their employees. By doing so, employees performance will increase as well as organizational performance.

Most of the respondents, $42.5 \%$ disagreed that the evaluation result is revised by the responsible person; whereas $14.2 \%$ strongly disagreed with the statement. In order to assure the performance evaluation process is in accordance with the rule and regulation and to avoid bias and subjectivity responsible body need to revise the result and independent department/case team/or core process is better to evaluate the performance prior. Generally, in Adigrat public sectors employees' performance evaluation result is not revised by the responsible person. This result is in line with the result of (Mulugeta, 2013) at Zemen bank. 


\subsection{Employee's Perception on Criteria's of Performance Appraisal}

Table 4.3 Employee's Response on Criteria's of Performance Appraisal

\begin{tabular}{|c|c|c|c|c|c|c|c|c|c|c|c|c|c|c|}
\hline \multirow[t]{2}{*}{ Activities } & \multicolumn{2}{|c|}{$\begin{array}{c}\text { Strongly } \\
\text { agree }\end{array}$} & \multicolumn{2}{|c|}{ Agree } & \multicolumn{2}{|c|}{ Moderate } & \multicolumn{2}{|c|}{ Disagree } & \multicolumn{2}{|c|}{$\begin{array}{l}\text { Strongly } \\
\text { disagree }\end{array}$} & \multicolumn{2}{|c|}{ Total } & \multirow[t]{2}{*}{$\mu$} & \multirow[t]{2}{*}{ SD } \\
\hline & No. & $\%$ & No. & $\%$ & No. & $\%$ & No. & $\%$ & No. & $\%$ & No. & $\%$ & & \\
\hline $\begin{array}{c}\text { Knowledge of the } \\
\text { job is a factor in } \\
\text { PA }\end{array}$ & 22 & 12.6 & 102 & 58.6 & 27 & 15.6 & 22 & 12.6 & 1 & .6 & 174 & 100 & 2.3 & 0.868 \\
\hline $\begin{array}{l}\text { In PA, quality of } \\
\text { work taken as a } \\
\text { factor }\end{array}$ & 31 & 17.8 & 72 & 41.4 & 43 & 24.7 & 23 & 13.2 & 5 & 2.9 & 174 & 100 & 2.42 & 1.021 \\
\hline $\begin{array}{c}\text { Initiation is a } \\
\text { critical factor in } \\
\text { PA }\end{array}$ & 50 & 28.7 & 65 & 37.4 & 27 & 15.5 & 26 & 14.9 & 6 & 3.4 & 174 & 100 & 2.27 & 1.134 \\
\hline $\begin{array}{l}\text { Interpersonal } \\
\text { relationship is } \\
\text { critical in PA }\end{array}$ & 36 & 20.7 & 60 & 34.5 & 37 & 21.3 & 38 & 21.8 & 3 & 1.7 & 174 & 100 & 2.49 & 1.100 \\
\hline & & & & & & & & greg & nea & $\mathrm{dd} \mathrm{st}$ & $\operatorname{ard} c$ & ation & 2.4 & 1 \\
\hline
\end{tabular}

Source: Own Questionnaire, 2018

As we observe from the above Table 4.3, 12.6\% strongly agreed, 58.6\% agreed that knowledge of the job is a factor in performance appraisal.15.6\% become moderate on the idea. The mean score 2.3 confirms that knowledge of the job is a factor in PA.

Regarding the quality work, $17.8 \%$ strongly agreed, $41.4 \%$ agreed that quality of work is a critical factor in performance appraisal, $24.4 \%$ moderate. The mean score 2.4 indicates respondents agreed with the statement that the quality of the work is a factor in performance appraisal. This criterion includes the completion of tasks in thorough, accurate and timely and manner that achieve expected results.

For the item on "Initiative or commitment is also a factor in performance evaluation", $28.7 \%$ strongly agreed that initiative is a factor in performance appraisal and $37.4 \%$ agreed whereas $14.9 \%$ moderate. The mean score 2.27 indicates they positively agreed with the idea that initiative or commitment is a factor in performance appraisal. This indicates that employees have the responsibility in performing duties, an ability to offer assistance to others to support the goals and objectives of the organization.

\subsection{Employees Perception on Challenges of Performance Appraisal}

Table 4.4 Employees Response on Challenges of Performance Appraisal

\begin{tabular}{|c|c|c|c|c|c|c|c|c|c|c|c|c|c|c|}
\hline \multirow[t]{2}{*}{ Activities } & \multicolumn{2}{|c|}{$\begin{array}{c}\text { Strongly } \\
\text { agree }\end{array}$} & \multicolumn{2}{|c|}{ Agree } & \multicolumn{2}{|c|}{ Moderate } & \multicolumn{2}{|c|}{ Disagree } & \multicolumn{2}{|c|}{$\begin{array}{l}\text { Strongly } \\
\text { disagree }\end{array}$} & \multicolumn{2}{|c|}{ Total } & \multirow[t]{2}{*}{$\boldsymbol{\mu}$} & \multirow[t]{2}{*}{ SD } \\
\hline & No. & $\%$ & No. & $\%$ & No. & $\%$ & No. & $\%$ & No. & $\%$ & No. & $\%$ & & \\
\hline $\begin{array}{c}\text { Employees do not } \\
\text { know the factors in PA }\end{array}$ & 3 & 1.7 & 14 & 8 & 24 & 13.8 & 119 & 68.4 & 14 & 8 & 174 & 100 & 3.73 & 0.791 \\
\hline $\begin{array}{c}\text { Employees are given } \\
\text { feedback at the time of } \\
\text { conducting PA result } \\
\text { only }\end{array}$ & 26 & 14.9 & 103 & 59.2 & 17 & 9.8 & 26 & 14.9 & 2 & 1.1 & 174 & 100 & 2.28 & 0.935 \\
\hline $\begin{array}{c}\text { Supervisors are not } \\
\text { accountable their } \\
\text { wrong feedback } \\
\end{array}$ & 2 & 1.1 & 7 & 4 & 17 & 9.8 & 122 & 70.1 & 26 & 14.9 & 174 & 100 & 3.94 & 0.714 \\
\hline $\begin{array}{l}\text { The PE process used } \\
\text { as punishment for poor } \\
\text { performance }\end{array}$ & 25 & 14.4 & 91 & 52.3 & 23 & 13.2 & 34 & 19.5 & 1 & .6 & 174 & 100 & 2.40 & 0.978 \\
\hline $\begin{array}{l}\text { Supervisors/managers } \\
\text { are not well trained in }\end{array}$ & 29 & 16.7 & 82 & 47.1 & 30 & 17.2 & 26 & 14.9 & 7 & 4 & 174 & 100 & 2.43 & 1.06 \\
\hline $\begin{array}{l}\text { Employees do not have } \\
\text { the chance to give } \\
\text { feedback while } \\
\text { conducting the result. }\end{array}$ & 6 & 3.4 & 21 & 12.1 & 34 & 19.5 & 99 & 56.9 & 14 & 8 & 174 & 100 & 3.54 & 0.92 \\
\hline & & & & & & & & ega & ean & $\mathrm{d}$ st & $\operatorname{ard}$ & ation & 2.9 & 0.9 \\
\hline
\end{tabular}

Source: Own Questionnaire; 2018 
As we observe in the above Table 4.4, $1.7 \%$ strongly agreed, $8 \%$ agreed that employees do not know the factors in performance appraisal, $13.8 \%$ become moderate. But the majority of the respondents disagreed with the idea i.e. $68.4 \%$ disagreed, $8 \%$ strongly disagreed that employees do not know factors in performance evaluation. The mean score 3.74 indicates that respondents disagreed to the idea that employees do not know the factors. This means employees know the factors in performance appraisal.

Regarding the feedback, $14.6 \%$ strongly agreed that feedback/comment is given at the time of conducting performance appraisal result only moreover $59.6 \%$ agreed to the idea while $9.8 \%$ moderate. However, $14.9 \%$ disagreed, $1.1 \%$ strongly disagreed that feedback is given at the time of conducting PA result only. The mean score for this issue is 2.28 , which indicate that they positively agreed to the idea that feedback is given at the time of conducting performance appraisal result. But feedback should be given not at the time of conducting performance appraisal rather it should be given frequently this helps employees to know their strength and weakness on time. Moreover, effective performance feedback has the potential to improve employee commitment, motivation, and satisfaction. And it should be given with a positive attitude as this can have an effect on the future employees' future performance.

Most of the respondents $70.1 \%$ disagreed, $14.9 \%$ strongly disagreed that supervisors are not accountable for their wrong feedback, mean that supervisors are accountable for their wrong feedback. The mean score 3.9 indicates the majority of the respondents disagreed with the issue. This means that supervisors are accountable for their wrong feedback.

Even though supervisors are accountable for their wrong feedback, the majority of employee's response agreed that performance evaluation is used as punishment for poor performers i.e. $52.3 \%$ agreed, $14.4 \%$ strongly agreed.

Regarding supervisors or case team coordinators or managers training, $16.7 \%$ strongly agreed, $47.2 \%$ agreed that supervisors or case team coordinators or managers are not well trained in assessing and giving feedback. From this, we can understand that supervisors or case team coordinators or managers are not well trained in assessing and giving feedback thus they will face difficulties on how to enhance the profession of their employees/subordinates / and potential employees start to look for other opportunities for them. This leads also disagreement between subordinates and their leaders and if there is disagreement between them, they will not be effective in their work.

For the question on, "employees do not have the chance to give feedback while conducting the result", the majority of the respondents disagreed with the statement i.e. 56.9\% disagreed, $8 \%$ strongly disagreed mean that employees have a chance to give feedback or there are two-way communications among them. The mean score 3.54 indicates that employees/subordinates disagreed with idea that employees do not have the chance to give feedback. To the reverse, this indicates they have chance to give feedback.

\subsection{ANOVA Tests}

The questionnaire survey included basic questions on the existing Performance Appraisal Process with 9 items aggregated into Total Measurement of Performance Appraisal Process/System (TPA Process) existing in Public Sector Organizations of Adigrat (Ethiopia), followed by Total Measurement of Performance Appraisal Methods (TPA Methods) aggregated by 9 items, Total Measurement of Performance Appraisal Criterions (TPA Criteria) with 5 items, Total Measurement of Performance Appraisal Challenges (TPA Challenge) with 11 items, and the overall measurement of Performance Appraisal (TPA) Dimensions aggregated by this sub aggregated items.

From the ANOVA Table 4.5 it is inferred that the Availability of Performance Appraisal Process/System (TPA Process $)$ is highly significant across Age $(\mathrm{F}=17.139 \mathrm{Sig}=.000)$, as well as by Work Experience $(\mathrm{F}=10.384$, $\mathrm{Sig}=.000$ ). It is also inferred that the Availability of Performance Appraisal Methods (TPA Methods) is highly significant across Age $(\mathrm{F}=11.692 \mathrm{Sig}=.001)$, as well as by Work Experience $(\mathrm{F}=7.809, \mathrm{Sig}=.000)$. In the case of Availability of Performance Appraisal Criterion (TPA Criteria), it is highly significant across Work Experience $(\mathrm{F}=7.282, \mathrm{Sig}=.000)$. And the overall measurement of the various dimensions of Performance Appraisal (TPA) in the case of Public Sector Organizations is highly significant across Age $(\mathrm{F}=11.855 \mathrm{Sig}=$ $.001)$, as well as by Work Experience $(\mathrm{F}=8.562$, Sig $=.000)$. From these findings it can also be proposed that Age and Work experience have a significant effect on the perception of Performance Appraisal System at the Workplace, especially in public sector context, and there are lacunae in the public sector system on proper implementation of Performance Appraisal System that is studied in detail in this paper within the scope of the conceptual framework adopted. 
Table 4.5 ANOVA Tests

\begin{tabular}{|c|c|c|c|c|c|c|}
\hline & & Sum of Squares & df & Mean Square & $\mathbf{F}$ & Sig. \\
\hline \multirow{3}{*}{$\begin{array}{c}\text { TPA Process* BY } \\
\text { AGE }\end{array}$} & Between Groups & 872.377 & 1 & 872.377 & 17.139 & .000 \\
\hline & Within Groups & 8754.589 & 172 & 50.899 & & \\
\hline & Total & 9626.966 & 173 & & & \\
\hline \multirow{3}{*}{$\begin{array}{l}\text { TPA Methods* BY } \\
\text { AGE }\end{array}$} & Between Groups & 394.523 & 1 & 394.523 & 11.692 & .001 \\
\hline & Within Groups & 5804.006 & 172 & 33.744 & & \\
\hline & Total & 6198.529 & 173 & & & \\
\hline \multirow{3}{*}{ TPA* BY AGE } & Between Groups & 2783.406 & 1 & 2783.406 & 11.855 & .001 \\
\hline & Within Groups & 40383.053 & 172 & 234.785 & & \\
\hline & Total & 43166.460 & 173 & & & \\
\hline \multirow{3}{*}{$\begin{array}{l}\text { TPA Process* BY } \\
\text { WORKEXP }\end{array}$} & Between Groups & 1490.887 & 3 & 496.962 & 10.384 & .000 \\
\hline & Within Groups & 8136.078 & 170 & 47.859 & & \\
\hline & Total & 9626.966 & 173 & & & \\
\hline \multirow{3}{*}{$\begin{array}{l}\text { TPA Methods* BY } \\
\text { WORKEXP }\end{array}$} & Between Groups & 750.744 & 3 & 250.248 & 7.809 & .000 \\
\hline & Within Groups & 5447.785 & 170 & 32.046 & & \\
\hline & Total & 6198.529 & 173 & & & \\
\hline \multirow{3}{*}{$\begin{array}{l}\text { TPA Criteria* BY } \\
\text { WORKEXP }\end{array}$} & Between Groups & 289.525 & 3 & 96.508 & 7.282 & .000 \\
\hline & Within Groups & 2252.935 & 170 & 13.253 & & \\
\hline & Total & 2542.460 & 173 & & & \\
\hline \multirow{3}{*}{$\begin{array}{l}\text { TPA* BY } \\
\text { WORKEXP }\end{array}$} & Between Groups & 5666.147 & 3 & 1888.716 & 8.562 & .000 \\
\hline & Within Groups & 37500.313 & 170 & 220.590 & & \\
\hline & Total & 43166.460 & 173 & & & \\
\hline
\end{tabular}

Source: Own Questionnaire, 2018

\section{Conclusions and Recommendations}

\subsection{Conclusions}

According to performance appraisal manual, the objectives of performance appraisal for employees of public sector is to, improve upon employees performance through counseling that motivate individual development, to let employees know how they are performing ,to give deserved recognition, to clear vague responsibilities, to motivate and assist the employees in growing within his/her job, to provide a record of employees growth patterns and to identify training needs, to serve as a supervisory tool which will help managers and supervisors heighten their supervisory ability and to heighten their understanding of their employees, to assist in diminishing favoritism that may exist, to improve employee-management communication and to identify individual skills being used in the employees present position.

Performance evaluation criteria and standards of the sectors are established based on the job description of employees and criterions are associated with the objective and goal of the office. The majority of employees are sensitive of how the performance appraisal process is conducted or there is communication how performance appraisal is conducted. Moreover, employees are allowed to evaluate themselves using proper format prior to the final result and also there is an open discussion between appraise and appraiser. In getting employees further career/promotion/reward, recognition, long-term training, and job designation as a result of their performance are not at the desired level. But these HR decisions are critical for employees as well as the sector and effectiveness of the performance appraisal process.

To get employee's further HR decision, employees' performance is evaluated by comparing multiple years result i.e. 18 months (1year and 6month) and employees are evaluated with co-workers. This helps to see the progress of their performance and to compare good performers and low performers.

Since majority of employees are evaluated with the same criteria, it is difficult to know individual's performance result regarding to their knowledge, skill and other behaviors but, different in weight because employees' job duties and responsibilities are different according to their profession and since there is shortage of time and carelessness in hearing and addressing employees' problem regarding performance appraisal, evaluation result is not revised by responsible person.

Performance appraisal is not conducted fairly and free from biases because there are some subjective criteria's and supervisors, case team coordinators and head office are not well trained in assessing and giving feedback (comments are given at the time of conducting performance appraisal result only. 
Regarding the criteria's of performance appraisal, the information got from respondents, some of the criteria's for performance appraisal are quality of work, timeliness, quantity and finance and the majority of employees know these factors. Employees are evaluated on the four perspectives at the moderate level.

Supervisors/managers are influenced by their personal liking and disliking when evaluating employee's performance. If there are personal liking and disliking, there is no loyalty between them. But they are accountable for their wrong feedback this is a positive side of the organization. Public sectors used performance evaluation as punishment for poor performers. Supervisors or case team coordinators or managers are not well trained in assessing and giving feedback this can lead them giving unfair performance result and then employees moral to work decreases.

The major performance appraisal challenges raised from interviewees are, not having computer skill, no consistent training for appraiser and appraise, there are some criteria's subjective like attitude, self-evaluating by two weeks, culture in giving performance result, complain towards their result, disagreement among civil service and other sectors and informal performance appraisal step or individual scores exceeds team performance or the sector performance. Time-consuming process, in most public sectors at this time performance appraisal is disconnected from reward, promotion, long-term training etc that is way, supervisors, case team coordinators; head offices do not give attention for performance evaluation.

\subsection{Recommendations}

Since performance appraisal is very important to employees in public sector, the appraisers should give attention for PA and employees could be benefited based on their performance and the strategy for career development should give chance for all sectors and employees as required. Majority of employees are evaluated with the same criteria. But to measure employees result, the criteria's is supposed to be designed according to organization goals and objectives and employee's job duties and responsibilities because the nature of work, one's knowledge, skill, behavior and profession etc. are different.

Since performance evaluation result is important for employees and organization, appraisers and appraise should have enough time and timely feedback and also raters should use their time efficiently. To avoid biases like personal liking and dislike, subjective criteria's, infrequent feedback, non-data assessment, recent behavior bias, etc. developing a plan that can direct and control the existence of such practices and public sector should develop methods of recording both negative and positive performance and evaluation result should be revised by responsible authority.

In order to improve the organization and employee's performance, employees should be given on time feedback/comment. To protect employees from punishment, managers or supervisors should always be communicating with their subordinates about how they are performing and they should not wait until the final result, giving regular feedback, providing training to managers, doing the evaluation on time, doing more on behavioral change shall result in effective performance evaluation.

\section{References}

1. Adeba, H. (2014). Practices and challenges of employee's performance appraisal in the Ministry of Culture and Tourism of Ethiopia. International Journal of Academic Research, ISSN: 2348-766, 1(2/2), JulySeptember, 2014. Adds Ababa University, Ethiopia.

2. Aguinis, H. (2009). An expanded view of performance management in J. w. Smither\& M. London (ed.), performance: putting research into practice (pp. 1-43). San Francisco: Wiley.

3. Ambani, K.M. (2016). Effect of Employee Involvement on Job Performance: at the Kenya Medical Research Institute (Centre for global health research) Kisumu.

4. Aquinas, P.G. (2006). Human resource management: principles and practices. New Delhi: vikas publishing house.

5. Armstrong, M. (2009). Handbook of performance management an evidence-based guide to delivering high performance, 4th edition, London Kogan page limited.

6. Arup, S. (2008). A critical analysis of performance appraisal system for teachers in public sector university of Pakistan: case study of the Islamia University of Bahawalpur (IUB). African journal of business management, 5(9), 3735-3744.

7. Asrat, A. (2016). Assessment of human resource management practices towards organizational performance: in the case of Addis Ababa university.

8. Aswathappa, A. (2002). Human Resource and personnel management: Text and Cases, 3rd edition, Tata McGraw-Hill Publishing Company Limited, New Delhi, pp. 199-231. 
9. Bibhuti, Bhusan and Mahapatro, (2010). Human resource management: New Delhi, new age international private limited, publisher.

10.Buford and Linder, (2002). Human resource management in local government: concepts and applications for HRM students and practitioners.

11.Chepkemoi, N. (2013). Education for Sustainable Development for Deputies, Deans and HODs of Teachers Training Colleges-Kenya Education Management institute, Nairobi.

12.Creswell, J.W. (2003). Research design: A qualitative, quantitative, and mixed method approach (2nd Ed.). Thousand oaks, CA: Sage.

13.Daoanis, L.E. (2012). Performance appraisal system: it's implication to employee performance: International journal of economics and management science, 2(3), 55-62.

14.Decenzo, D. \& Robbins, S. (2005). Fundamentals of human resource management (8thed.) USA: von Hoffmann press.

15.Dewakar, G. (2009). Human resource management: Delhi, pp. 26-60.

16. Ikramullah, Shah, B., Hassan, F.S.U., Zaman (2012). Purpose of performance appraisal system: A perceptual study of civil servants in district dera Ismail khan Pakistan. International Journal of Business and management, 7(3), 142-151. http://dx. Doi org /10.5539/ijbm.v7n3p142.

17.Ivancevich, J.M. (2004). Human resource management (9th ed.). McGraw-publisher: Boston.

18.Jafari, M., Bourouni, A., Amiri, R. (2009). A New Framework For Selection of the Best performance appraisal Method. European Journal of Social Sciences, 7(3), 92-100.

19.John, S. (2011). The top 50 challenges with performance appraisal. Available at: www.tlnt. Com.

20.Johnston, A. (2010). Sampling hard-to-reach population with respondent driven sampling: Methodological innovation online, 5(2), 38-48.

21.Kothari, C.R. (2004). Research Methodology, Methods and Techniques. 2nd Edition, pp. 86. New Age International Publishers, New Delhi.

22.Kokemuller, N. (2012). The pros \& cons of performance appraisal methods. Available at: http://smallbusiness.chrom.com/pros-cons-performance-appraisal-methods-39497.html.

23.Lotich, P. (2014). Advantages and disadvantages of performance appraisals. Available at: $\mathrm{http}: / /$ thethriviingsmallbusiness.com/advantages and-disadvantages -of-performance -appraisal/.

24. Mamoria, C. \& Rao, V. (2012). Personnel management (13th ed.). Mumbai: Himalaya management, 16(1), 76-81.

25.Marczyk, G. and Dematteo, D. (2005). Essentials of research design and methodology. Published by John Wiley, New Jersey.

26.Mulugeta, H. (2013). Employee's performance evaluation practices and challenges at Zemen bank: St. Mary's university college.

27.Ngwenya, V. (2010). Managing parental involvement with education in Zimbabwe. Ph dissertation education management, University of South Africa, November 2010.

28.Paul, R. N. (2014). Balanced scorecard evolution, dynamic approach to strategy execution: John Wiley and sons, Inc, Canada.

29.Raymond, A. Noe. (2011). Fundamentals of human resource management, Newyork: McGraw-Hill Companies Inc.

30.Rao, C.M. (2012). Personnel management: 30th edition Himalaya publishing house.

31.Saqib, Khan, M., Ahmed, M., \& Ullah, I. (2012). A brief Review of Performance Appraisal Practices and its Implementation at Government Offices in Pakistan. Interdisciplinary journal of contemporary research in business, 3(10), 1057-1060.

32.Seidu, P. A. (2012). Employees' Perception of Performance Appraisal System: A Case Study. International Journal of Business and Management, 7(2), 73-88.

33.Tilahun, G., \& Yimam, T. (2014). Is the Role of Teachers Performance in Ethiopia Rhetoric or Reality? Convergence between Knowledge and Implementation and Findings Solutions from the Process. Ethiopian Journal of Education and Sciences, 10(1), 89. Accessed (1st Oct 2018) from: https://www.ajol.info/index.php/ejesc/article/viewFile/120593/110043.

34. Yamane, T. (1967). Statistics: An Introductory Analysis, 2nd Edition. New York: Harper and Row.

35.Yong, A. K. (1996). Malaysian Human Resource Management: Kuala Limper: Malaysian institute of management.

36.Zikgmund, W.G., Barry, J., Babine, J.C. and Carr, M.G. (2004). Business research methods, 9th edition, New York: The Dryden press.

37.Zona, F., Minoja, M., \& Coda, V. (2013). Antecedents of Corporate Scandals: CEOs' Personal Traits, Stakeholders' Cohesion, Managerial Fraud, and Imbalanced Corporate Strategy. Journal of Business Ethics, 113(2), 265-283. https://doi.org/10.1007/s10551-012-1294-6. 